\title{
P53 Overexpression in Ductal Carcinoma in situ of the Breast
}

\author{
Kikuchi $\mathbf{S}^{1,3}$, Osako $\mathbf{T}^{1}$, Nishiyama $\mathbf{Y}^{1}$, Nakano $\mathbf{M}^{1}$, Tashima $\mathbf{R}^{1}$, Fujisue $\mathbf{M}^{1}$, Toyozumi $\mathbf{Y}^{2}$, Arima $\mathbf{N}^{2}$ and Nishimura $\mathbf{R}^{1^{*}}$ \\ ${ }^{1}$ Department of Breast and Endocrine Surgery, Kumamoto City Hospital, Kumamoto 862-8505, Japan \\ ${ }^{2}$ Departments of Breast Clinical Pathology, Kumamoto City Hospital, Kumamoto, Japan \\ 3JSDF Kumamoto Hospital, Kumamoto 862-8505, Japan
}

*Corresponding author: Reiki Nishimura, Department of Breast and Endocrine Surgery, Kumamoto City Hospital, Kumamoto, 1-1-60 Kotoh, Higashi-ku, Kumamoto City, Kumamoto 862-8505, Japan, Tel: +81-96-365-1711; Fax: +81-96-365-1712; Email: nishimura.reiki@cityhosp-kumamoto.jp

Rec date: Jul 10, 2014, Acc date: Jul 26, 2014, Pub date: Jul 28, 2014

Copyright: $\odot 2014$ Kikuchi S, et al. This is an open-access article distributed under the terms of the Creative Commons Attribution License, which permits unrestricted use, distribution, and reproduction in any medium, provided the original author and source are credited.

\begin{abstract}
:
Background: Ductal carcinoma in situ (DCIS) is the most common type of non-invasive breast cancer. DCIS is not life threatening but can increase the risk of invasive ductal carcinoma (IDC) development. However, the role of P53 expression in the progression to invasiveness in DCIS is unclear. In this retrospective study, the differences in biological markers, including protein 53 (P53) expression, between DCIS and IDC $\leq 5 \mathrm{~mm}$ in diameter (T1a) were evaluated.
\end{abstract}

Methods: Among 2,497 primary breast cancer patients, who underwent initial surgery between 2001 and 2010, $267(10.4 \%)$ patients were diagnosed with DCIS and $86(3.4 \%)$ patients were diagnosed with T1a. P53 expression was evaluated using immunohistochemical analysis, and the distribution $(<10 \%,<50 \%$, and $\geq 50 \%)$ and the association with other biological markers was investigated in DCIS and T1a.

Results: Overexpression ( $\geq 50 \%$ ) of P53 was seen in $13 \%$ of patients with DCIS and in $24 \%$ of patients with T1a, constituting a significant difference $(p=0.001)$. P53 overexpression was significantly associated with higher nuclear grade, lower rates of estrogen receptor $(E R) /$ progesterone receptor $(\mathrm{PgR})$ positivity, higher rates of epidermal growth factor receptor 2 (HER2) positivity, and higher values of nuclear protein Ki-67 in patients with DCIS. Recurrence rates did not differ significantly between DCIS and T1a. Logistic regression analysis of factors associated with invasiveness revealed that P53 overexpression was one of the significant factors, and ER negativity was found to be a significant independent factor in multivariate analysis.

Conclusion: P53 overexpression reflected the aggressiveness and correlated with the invasiveness in DCIS. These findings suggest that P53 may play an important role in invasion of DCIS in the breast.

Keywords: P53 overexpression; DCIS; Invasiveness

\section{Introduction}

Ductal carcinoma in situ (DCIS) is the most common type of noninvasive breast cancer, in which cancer cells do not grow beyond the basal membrane of the duct [1]. DCIS is associated with a low risk of recurrence; however, it has been considered a precursor of invasive ductal carcinoma (IDC). Since the introduction of mammography in breast cancer screening, increasing numbers of cases of DCIS are now being identified and the frequency has increased to 15-20\% [2]. In patients treated with breast-conserving surgery, half of the DCIS cases with ipsilateral breast tumor recurrence (IBTR) were observed to have invasive components. Moreover, a few cases with DCIS had distant metastases [3-6]. It is still unclear how to differentiate cases of DCIS with high risk of recurrence from those cases with originally low risk of recurrence. Histopathological factors $[7,8]$ including nuclear grade, the presence of necrosis, tumor size, and surgical margin status were reported to be related to the risk of IBTR in DCIS. Surgical margin status was considered the most important factor for IBTR among patients with DCIS treated with breast-conserving surgery [8]. In our institute, intraoperative pathological examination is performed during primary surgery, to monitor surgical margin status with an aim to achieve negative margin status. This system eliminates the risk of leaving cancer cells behind during primary surgery. Furthermore, several biological markers including human epidermal growth factor-2 (HER2), estrogen receptor (ER), Ki-67, and P53 have also been reported to be related to the risk of IBTR in DCIS [4-6,9-11].

Among these biological markers, P53 overexpression was introduced as a predictor of IBTR in patients with DCIS $[9,12]$. P53 has been widely applied as a prognostic marker in invasive breast cancer, and its overexpression, $70 \%$ or $80 \%$ of them reported as mutant, has been correlated with poor prognosis [13-16]. Recently, Muller et al. reported that mutant p53 could acquire new functions to drive cell migration and invasion [17]. However, few reports have investigated the role of P53 expression in DCIS of the breast $[3,10,18]$. The role of P53 overexpression remains unclear in DCIS of the breast. To date, several reports have described the biomarker profiles of patients with DCIS and the correlations among markers such as HER2, Ki-67, P53, and hormone receptors $[3,10,18]$.

In this study, we evaluated the clinicopathological significance of P53 for local invasion in DCIS and the use of several biomarkers in detecting DCIS associated with a high risk of recurrence. 


\section{Materials and Methods}

\section{Patients}

Among 2,497 primary breast cancer patients who underwent initial surgery between 2001 and 2010, 267 patients (10.4\%) with DCIS and $86(3.4 \%)$ patients withIDC $\leq 5 \mathrm{~mm}$ in diameter (T1a) were enrolled in this retrospective study. The age of the patients ranged from 25 to 86 years (mean, 54.0 years) in patients with DCIS and from 30 to 80 years (mean, 56.0 years) in patients with T1a. Of the 267 patients with DCIS and the 86 patients with T1a, $228(85 \%)$ and $57(66 \%)$ patients were ER-positive, $210(79 \%)$ and $48(56 \%)$ patients were progesterone receptor (PgR)-positive, $51(19 \%)$ and 32 (37\%) patients were HER2positive, and 71(27\%) and $39(45 \%)$ cases were Ki-67-positive ( $\geq 20 \%)$, respectively. Of the cases of P53 overexpression, 35 (13\%) were of DCIS and $21(24 \%)$ were of T1a. Breast-conserving surgeries were performed for 160 patients with DCIS (60\%) and 56 patients with T1a (65\%). All the cases received postoperative radiotherapy (Table 1).

We used to take the pharmacological anamnesis of the patients for standard therapy of breast cancer before surgical removal, such as the history of other cancer, concomitant medical disease like diabetes mellitus or asthma.

\section{Treatment and follow-up}

For patients with IDC, postsurgical follow-up examinations were performed every 3months until 3 years after surgery, every 3-6 months until 3-5 years after surgery, and every 6-12 months up to 510 years after surgery. Once a year, the patients underwent chest radiography, mammography, tumor marker tests, and abdominal ultrasonography; computed tomography was performed after consultation with the patients. In cases of DCIS, the patients were followed-up for 10 years with annual mammography.

\section{Histopathological examination}

Histopathological examination was performed by 2 pathologists (T.Y. and A.N.) to determine the presence of lymph node metastasis, nuclear grade, ER/PgR status, Ki-67 labeling index, HER2 status, and P53 expression. ER, PgR, p53, Ki-67, and HER2 expression were determined using immunostaining as described previously $[13-15,16,19]$. ER and PgR positivity was defined as the presence of $\geq 1 \%$ positive cells. Ki-67 immunostaining (clone MIB-1; Dako, Glostrup, Denmark) was used to assess the proliferation rate. The fraction of proliferating cells was based on a count of at least 500 tumor cellsin the area including the hot spot. Ki-67 values were expressed as the percentage of positive cells in each case. Cases with a Ki-67 index $\geq 20 \%$ were defined as positive, and cases with a Ki-67 index $<20 \%$ were defined as negative. The expression of P53 and HER2 was evaluated with immunohistochemical analysis (labeled streptavidin-biotin method) by using a mouse monoclonal anti- P53 antibody (clone DO7; Dako) and the rabbit monoclonal antibody (4B5, Ventana), respectively. The P53 staining pattern was classified into 3 groups: $2+$ (homogeneous and diffuse staining, $\geq 50 \%$ of cancer cells), $1+$ (heterogeneous or focal staining, $10-49 \%$ of cancer cells), and negative (focal staining, $<10 \%$ of cancer cells) (Figure 1). P53 overexpression was defined as P53 expression in $\geq 50 \%$ of cancer cells [14]. The HER2 staining pattern was divided into 4 groups: $3+$, strong and diffuse staining in $\geq 30 \%$ of cancer cells; $2+$, moderate and diffuse staining; 1+, focal staining; and negative. HER2-positive cases were defined as $3+$ or $2+$ with a fluorescence in situ hybridization (FISH) amplification ratio $\geq 2.2$, and HER2-negative cases were defined as negative, $1+$, or $2+$ with a FISH amplification ratio $<2.2$. The association between surgical margin status and P53 overexpression was also investigated. Positive surgical margin status was defined as cancer cells $\leq 5 \mathrm{~mm}$ from the edge of the excised specimen.

\begin{tabular}{|c|c|c|c|c|}
\hline & & DCIS & T1a & \\
\hline Factors & Category & 267 cases & 86 cases & $\begin{array}{l}\text { Pvalue } \\
\text { ( } \mathrm{X}^{2} \text { test) }\end{array}$ \\
\hline $\begin{array}{l}\text { Age (years) } \\
\text { (range) }\end{array}$ & & $\begin{array}{l}56.9 \pm 13.7 \\
(25 \sim 87)\end{array}$ & $\begin{array}{l}58.4 \pm 12.8 \\
(32 \sim 84)\end{array}$ & \\
\hline \multirow{2}{*}{$\begin{array}{l}\text { Menopausal } \\
\text { status }\end{array}$} & pre & $100(38 \%)$ & $32(37 \%)$ & \\
\hline & post & 164 & 54 & \\
\hline \multirow[t]{2}{*}{ Nuclear grade } & 3 & $19(7 \%)$ & $13(15 \%)$ & 0.001 \\
\hline & 1,2 & 239 & 72 & \\
\hline \multirow[t]{2}{*}{ ER } & + & 228 (85\%) & $57(66 \%)$ & 0.001 \\
\hline & - & 37 & 28 & \\
\hline \multirow[t]{2}{*}{ PgR } & + & 210 (79\%) & $48(56 \%)$ & $<0.0001$ \\
\hline & - & 55 & 37 & \\
\hline \multirow[t]{2}{*}{ HER2 } & + & $51(19 \%)$ & 32 (37\%) & 0.006 \\
\hline & - & 213 & 54 & \\
\hline \multirow[t]{2}{*}{ Ki-67 } & + & 71 (27\%) & $39(45 \%)$ & 0.002 \\
\hline & - & 193 & 47 & \\
\hline \multirow{2}{*}{$\begin{array}{l}\text { p53 } \\
\text { overexpressio } \\
\text { n }\end{array}$} & + & $35(13 \%)$ & $21(24 \%)$ & 0.001 \\
\hline & - & 228 & 65 & \\
\hline \multirow[t]{3}{*}{ Surgery } & $\mathrm{Bp}$ & $160(60 \%)$ & $56(65 \%)$ & 0.222 \\
\hline & $\mathrm{Bt}$ & 103 & 28 & \\
\hline & Unknown & 4 & 2 & \\
\hline \multirow{4}{*}{$\begin{array}{l}\text { Adjuvant } \\
\text { therapy }\end{array}$} & None & $182(68 \%)$ & $34(40 \%)$ & $<0.0001$ \\
\hline & $\begin{array}{l}\text { Chemother } \\
\text { apy }\end{array}$ & 7 & 9 & \\
\hline & $\begin{array}{l}\text { Endocrine } \\
\text { therapy }\end{array}$ & $72(27 \%)$ & $39(45 \%)$ & \\
\hline & $\begin{array}{l}\text { Chemo- } \\
\text { endocrine } \\
\text { therapy }\end{array}$ & 3 & 3 & \\
\hline Recurrence & with & $3^{*}$ & $1^{*}$ & \\
\hline site & $\begin{array}{l}\text { Ipsilateral } \\
\text { breast }\end{array}$ & $3^{*}$ & $1^{*}$ & \\
\hline
\end{tabular}

Table 1: Background clinicopathological factors in patients with IDC (T1a) and DCIS. 
Page 3 of 6

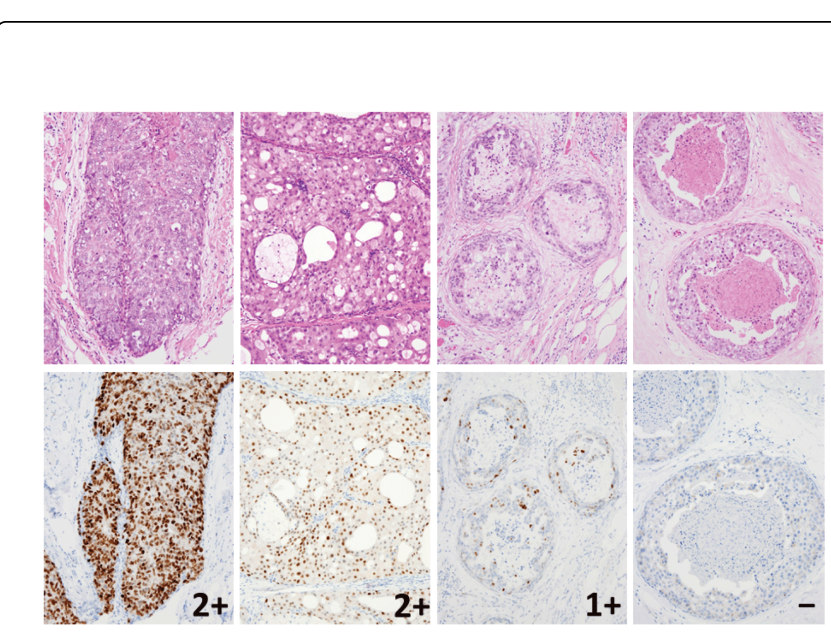

Figure 1a: H.E.staining and P53 immunostaining pattern in DCIS. (upper) H.E.staining (lower) P53 staining corresponding to upper H.E.staining. The P53 immunostaining pattern was classified into 3 groups: $2+$ (homogeneous and diffuse staining, $\geq 50 \%$ of cancer cells), $1+$ (heterogeneous or focal staining, $10-49 \%$ of cancer cells), and negative (focal staining, $<10 \%$ of cancer cells).

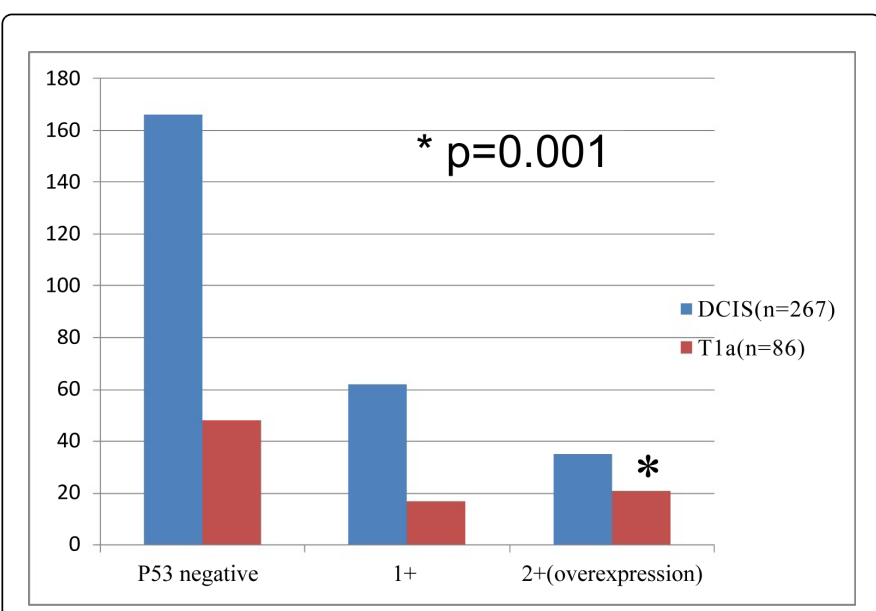

Figure 1b: P53 distribution in patients with DCI and T1a. P53 negativity, $1+$ expression, and $2+$ expression (overexpression) were observed in 166 cases (62\%), 62 cases (23\%), and 35 cases $(13 \%)$ of patients with DCIS and in 48 cases (56\%), 17 cases (20\%), and 21 cases $(24 \%)$ of patients with $\mathrm{T} 1 \mathrm{a}$, respectively. The P53 overexpression rate was significantly higher in patients with T1a $(\mathrm{p}=0.001)$.

\section{Statistical analysis}

The mean values were analyzed using the Student t-test and analysis of variance. Differences in clinicopathological factors between 2 groups or among 3 groups were evaluated using the $\chi 2$ test and Fisher exact test. A 2 -sided $\mathrm{p}$ value of $<0.05$ was considered statistically significant. Logistic regression analysis was used to estimate suitable factors for DCIS with invasion. Nuclear grade, ER-positive rate, HER2 status, Ki-67 index, and P53 overexpression were included in multivariate analysis. Statistical analyses were performed using the SPSS version 16.0 statistical package. The median observation period was 75 months from the initiation of treatment.

\section{Results}

\section{Distribution of p53 expression in DCIS and T1a}

Distribution of P53 expression in DCIS and T1a was investigated. The cases with P53 negativity, 1+ expression, and 2+ expression (overexpression) were observed in 166 cases (62\%), 62 cases (23\%), and 35 cases (13\%) of patients with DCIS and in 48 cases (56\%), 17 cases $(20 \%)$, and 21 cases $(24 \%)$ of patients with T1a, respectively. The P53 overexpression rate was significantly higher inT1a $(\mathrm{p}=0.001)$.

\section{Comparison of clinicopathological factors between IDC (T1a) and DCIS}

A comparison of clinicopathological factors, including P53 expression, between IDC (T1a) and DCIS is shown in Table 1. Nuclear grade, HER2, Ki-67, and P53 overexpression were significantly higher in IDC (T1a) than in DCIS ( $\mathrm{p}=0.001, \mathrm{p}=0.006, \mathrm{p}=0.002$, and $\mathrm{p}=0.001$, respectively), while ER and PgR were significantly lower in IDC (T1a) than in DCIS ( $\mathrm{p}=0.001$ and $\mathrm{p}<0.0001$, respectively). Three cases of DCIS and 1 case of T1a showed recurrence. Moreover, all cases had IBTR with invasive components.

Multivariate analysis of factors for invasion in DCIS and T1a tumors revealed that nuclear grade, ER positivity rates, HER2 status, Ki-67 index, and P53 overexpression were significant in univariate analysis $(\mathrm{p}=0.033, \mathrm{p}<0.0001, \mathrm{p}=0.001, \mathrm{p}=0.002, \mathrm{p}=0.016$, respectively). Among these factors, ER was the independent significant factor for invasiveness using multivariate analysis $(\mathrm{p}=0.041)$ (Table 2).

\begin{tabular}{|l|l|l|l|l|l|}
\hline Factors & \multicolumn{2}{|l|}{$\begin{array}{l}\text { Catego } \\
\text { ry }\end{array}$} & \multicolumn{2}{l|}{ Univariate analysis } & \multicolumn{2}{l|}{ Multivariate analysis } \\
\hline & & Odds ratio & Pvalue & Odds ratio & Pvalue \\
\hline Nuclear grade & 3 vs 2.1 & 0.440 & 0.033 & 1.107 & 0.825 \\
\hline ER & + vs - & 3.027 & $<0.0001$ & 2.148 & 0.041 \\
\hline HER2 & + vs - & 0.404 & 0.001 & 0.656 & 0.247 \\
\hline Ki-67 & + vs - & 0.443 & 0.002 & 0.647 & 0.197 \\
\hline $\begin{array}{l}\text { p53 } \\
\text { overexpression }\end{array}$ & + vs - & 0.475 & 0.016 & 1.062 & 0.883 \\
\hline
\end{tabular}

Table 2: Multivariate analysis of factors for invasion in DCIS and T1a tumors.

\section{Clinicopathological factors and P53 overexpression in DCIS and T1a}

Overexpression of P53 was observed in 13\% of the patients with DCIS. The relationship between P53 overexpression and clinicopathological factors in patients with DCIS and T1a was also investigated (Table $3 \mathrm{a}$ and $3 \mathrm{~b}$ ). P53 overexpression was found to significantly correlate with higher nuclear grade, negative $\mathrm{ER} / \mathrm{PgR}$ status, higher HER2 status, and higher Ki-67 index ( $<<0.0001)$. 
Citation: Kikuchi S, Osako T, Nishiyama Y, Nakano M, Tashima R, et al. (2014) P53 Overexpression in Ductal Carcinoma in situ of the Breast. J

Page 4 of 6

\section{Association between the surgical margin status and P53 overexpression}

In the cases with DCIS, 160 patients $(60 \%)$ received breastconserving surgery. HER2 status, Ki-67 labeling index and P53 overexpression was significantly associated with positive surgical margin status, among them P53 overexpression was found to be an independent factor $(\mathrm{p}=0.002)$ (Table 4). However, there were no cases with exposed cancer cells.

\begin{tabular}{|c|c|c|c|c|c|}
\hline \multirow[t]{2}{*}{ Factors } & \multirow[t]{2}{*}{ Category } & \multicolumn{3}{|c|}{ p53 expression } & \multirow[t]{2}{*}{$P$ value } \\
\hline & & $\begin{array}{l}\text { Negative } \\
(\mathrm{n}=166)\end{array}$ & $1+(n=62)$ & $\begin{array}{l}\text { Overexpres } \\
\text { sion }(n=35)\end{array}$ & \\
\hline $\begin{array}{l}\text { Age } \\
\text { (years) }\end{array}$ & $\begin{array}{ll}\text { Mean } & \pm \\
\text { SD } & \\
\text { (range) }\end{array}$ & $\begin{array}{l}58.5 \pm 14.0 \\
(25 \sim 87)\end{array}$ & $\begin{array}{l}54.4 \pm 13.1 \\
(26 \sim 81)\end{array}$ & $\begin{array}{l}58.3 \pm 12.8 \\
(32 \sim 84)\end{array}$ & 0.135 \\
\hline \multirow{2}{*}{$\begin{array}{l}\text { Nuclear } \\
\text { grade }\end{array}$} & 1,2 & 157 & 58 & 21 & \\
\hline & 3 & 4 & 2 & $13(38 \%)$ & $<0.0001$ \\
\hline \multirow[t]{2}{*}{ ER } & - & 11 & 5 & $21(60 \%)$ & \\
\hline & + & 155 & 57 & 14 & $<0.0001$ \\
\hline \multirow{2}{*}{ PgR } & - & 19 & 10 & $26(74 \%)$ & \\
\hline & + & 147 & 52 & 9 & $<0.0001$ \\
\hline \multirow[t]{2}{*}{ HER2 } & - & 149 & 49 & 13 & \\
\hline & + & 16 & 12 & $22(63 \%)$ & $<0.0001$ \\
\hline \multirow[t]{2}{*}{ Ki-67 } & - & 141 & 44 & 8 & \\
\hline & + & 25 & 18 & $24(69 \%)$ & $<0.0001$ \\
\hline \multirow[t]{2}{*}{ Surgery } & $\mathrm{Bp}$ & 90 & 42 & $26(74 \%)$ & \\
\hline & $\mathrm{Bt}$ & 74 & 19 & $9(26 \%)$ & 0.219 \\
\hline \multirow{4}{*}{$\begin{array}{l}\text { Adjuvant } \\
\text { therapy }\end{array}$} & None & 113 & 41 & $26(74 \%)$ & \\
\hline & $\begin{array}{l}\text { Chemoth } \\
\text { erapy }\end{array}$ & 0 & 1 & 5 & \\
\hline & $\begin{array}{l}\text { Endocrine } \\
\text { therapy }\end{array}$ & 49 & 19 & 4 & \\
\hline & $\begin{array}{l}\text { Chemo- } \\
\text { endocrine } \\
\text { therapy }\end{array}$ & 3 & 0 & 0 & \\
\hline \multirow[t]{5}{*}{ Subtype } & $\begin{array}{l}\text { Luminal } \\
\text { A-like }\end{array}$ & 125 & 38 & $4(11 \%)$ & \\
\hline & $\begin{array}{l}\text { Luminal } \\
\text { B-like }\end{array}$ & 18 & 10 & $6(17 \%)$ & \\
\hline & HER2 & 3 & 3 & $18(51 \%)$ & \\
\hline & $\begin{array}{l}\text { Luminal/ } \\
\text { HER2 }\end{array}$ & 13 & 9 & $4(11 \%)$ & \\
\hline & $\begin{array}{l}\text { Triple } \\
\text { Negative }\end{array}$ & 7 & 2 & $3(9 \%)$ & \\
\hline
\end{tabular}

Table 3a: p53 expression and clinicopathological factors in patients with DCIS.

\begin{tabular}{|c|c|c|c|c|c|}
\hline \multirow[t]{2}{*}{ Factors } & \multirow[t]{2}{*}{ Category } & \multicolumn{3}{|c|}{ p53 expression } & \multirow[t]{2}{*}{$P$ value } \\
\hline & & $\begin{array}{l}\text { Negative } \\
(\mathrm{n}=48)\end{array}$ & $1+(n=17)$ & $\begin{array}{l}\text { Overexpres } \\
\text { sion }(n=21)\end{array}$ & \\
\hline $\begin{array}{l}\text { Age } \\
\text { (years) }\end{array}$ & $\begin{array}{l}\text { Mean } \pm S D \\
\text { (range) }\end{array}$ & $\begin{array}{l}56.3 \pm 12.4 \\
(33 \sim 80)\end{array}$ & $\begin{array}{l}59.6 \pm 12.8 \\
(44 \sim 80)\end{array}$ & $\begin{array}{l}54.5 \pm 12.3 \\
(36 \sim 75)\end{array}$ & 0.454 \\
\hline \multirow{2}{*}{$\begin{array}{l}\text { Nuclear } \\
\text { grade }\end{array}$} & 1,2 & 43 & 14 & 15 & \\
\hline & 3 & 4 & 3 & $6(29 \%)$ & 0.100 \\
\hline \multirow[t]{2}{*}{ ER } & - & 9 & 4 & $15(71 \%)$ & \\
\hline & + & 38 & 13 & 6 & 0.001 \\
\hline \multirow[t]{2}{*}{ PgR } & - & 12 & 10 & $15(71 \%)$ & \\
\hline & + & 35 & 7 & 6 & 0.004 \\
\hline \multirow[t]{2}{*}{ HER2 } & - & 36 & 10 & 8 & \\
\hline & + & 12 & 7 & $13(62 \%)$ & 0.013 \\
\hline \multirow[t]{2}{*}{$\mathrm{Ki}-67$} & - & 38 & 7 & 2 & \\
\hline & + & 10 & 10 & $19(91 \%)$ & $<0.0001$ \\
\hline \multirow[t]{2}{*}{ Surgery } & $\mathrm{Bp}$ & 35 & 11 & $10(48 \%)$ & \\
\hline & $\mathrm{Bt}$ & 12 & 6 & $10(48 \%)$ & 0.263 \\
\hline \multirow{4}{*}{$\begin{array}{l}\text { Adjuvant } \\
\text { therapy }\end{array}$} & None & 18 & 4 & $12(57 \%)$ & \\
\hline & $\begin{array}{l}\text { Chemother } \\
\text { apy }\end{array}$ & 1 & 3 & 5 & \\
\hline & $\begin{array}{l}\text { Endocrine } \\
\text { therapy }\end{array}$ & 26 & 9 & 4 & \\
\hline & $\begin{array}{l}\text { Chemo- } \\
\text { endocrine } \\
\text { therapy }\end{array}$ & 2 & 1 & 0 & \\
\hline \multirow[t]{5}{*}{ Subtype } & $\begin{array}{l}\text { Luminal A- } \\
\text { like }\end{array}$ & 27 & 6 & $0(0 \%)$ & \\
\hline & $\begin{array}{l}\text { Luminal B- } \\
\text { like }\end{array}$ & 5 & 3 & $3(14 \%)$ & \\
\hline & HER2 & 6 & 3 & $9(43 \%)$ & \\
\hline & $\begin{array}{l}\text { Luminal/ } \\
\text { HER2 }\end{array}$ & 6 & 4 & $4(11 \%)$ & \\
\hline & $\begin{array}{l}\text { Triple } \\
\text { Negative }\end{array}$ & 7 & 2 & $3(9 \%)$ & \\
\hline
\end{tabular}

Table 3b: p53 expression and clinicopathological factors in patients with T1a.

\section{Discussion}

In this study, 267 patients with DCIS were analyzed to evaluate the clinical significance of P53 expression. Of the 267 patients with DCIS, 3 patients (1.1\%) had IBTR with invasive components. This recurrence rate was substantially lower than that in previous reports $[20,21]$. Surgical margin status was considered an important factor for local recurrence among patients with DCIS treated with breast-preserving surgery [8]. Moreover, half of the recurrent cases were reported to be invasive cancer [8]. The rates of positive surgical margins were higher 
in patients with P53 overexpression. However, there were no cases with exposed cancer cells due to intraoperative examination of margin status. P53 status should be considered in the decision regarding the surgical procedure, whether there is a need to perform breastconserving surgery.

\begin{tabular}{|l|l|l|l|l|l|}
\hline Factors & Category & \multicolumn{2}{|l|}{ Univariate analysis } & \multicolumn{2}{l|}{ Multivariate analysis } \\
\hline & & $\begin{array}{l}\text { Odds } \\
\text { ratio }\end{array}$ & Pvalue & $\begin{array}{l}\text { Odds } \\
\text { ratio }\end{array}$ & Pvalue \\
\hline Nuclear grade & 3 vs 2.1 & 1.636 & 0.652 & 7.798 & 0.101 \\
\hline ER & + vs - & 1.832 & 0.295 & 0.085 & 0.100 \\
\hline PgR & + vs - & 2.234 & 0.121 & 2.049 & 0.572 \\
\hline HER2 & + vs - & 0.358 & 0.034 & 0.329 & 0.112 \\
\hline Ki-67 & + vs - & 0.296 & 0.007 & 0.532 & 0.271 \\
\hline $\begin{array}{l}\text { P53 } \\
\text { overexpression }\end{array}$ & + vs - & 0.155 & $<0.0001$ & 0.077 & 0.002 \\
\hline
\end{tabular}

Table 4: Univariate and Multivariate analysis for the surgical margin status among $160(60 \%)$ patients with DCIS who received breastconserving surgery.

Several studies have reported on the predictive markers for microinvasion in DCIS. Nofech-Mozes et al. $[4,6]$ reported that HER2 was the predictive factor for DCIS microinvasion, and Okumura et al. [5] reported that survivin expression was an independent factor associated with invasion. In this study, the significant factors for invasiveness of DCIS were nuclear grade, ER and PgR, HER2 status, Ki-67 index, and P53 overexpression according to the results of the univariate analysis, while multivariate analysis revealed that ER negativity was an independent significant factor. Some investigators have reported that ER-positive breast cancer patients can experience loss of or a reduction in ERa, which is associated with P53 overexpression [22-24]. Furthermore, Dumpy reported that estrogen and progesterone induce persistent increases in p53-dependent apoptosis and suppress mammary tumors in BALB/c-Trp53+/- mice [25]. P53 overexpression was significantly associated with ER negativity in this study. P53 overexpression might correlate with DCIS invasion via the ER to some extent.

The vascular role of estrogens in different kind of vascular district was reported in several references [26-28]. Ciccone MM et al. reported that estrogen increased cerebral perfusions [26], reduced the vascular effects of isometric muscle contraction by modulating the vasomotor tone of peripheral vessels in relation to exercise [27], and increased ophthalmic artery perfusion in healthy postmenopausal women [28]. This is really important when considering the probability for DCIS breast cancer to give invasion or metastasis.

In terms of the rate of P53 overexpression, DCIS tumors had a positive rate of $13 \%$ and T1a had a positive rate of $24 \%$ using the cutoff point of 50\%. Nofech-Mozes et al. [4] reported the rate of P53 overexpression in DCIS as $22 \%$, and Rajan et al. [12] reported it to be18\%, which were both higher than the rate found in this study. Several other studies have investigated the role of P53 overexpression in DCIS. To date, 4 studies have examined the prognostic value of biological markers in DCIS. Ringberg et al. [11] reported that high levels of Ki-67, P53, and bcl-2 are significantly (or almost significantly) associated with disease recurrence in DCIS. Perin et al. [10] found no significant association between a wide variety of biological markers, including ER, PgR, HER2, and P53, and the rate of disease recurrence in 49 patients with DCIS who received mastectomy or breastconserving surgery with or without radiotherapy. de Roos et al. [9] reported that P53 is a common predictor of local recurrence in DCIS. Rajan et al. [12] reported that P53 is associated with comedo status, high nuclear grade, and high mitotic index in DCIS, and therefore represents a new parameter to evaluate the cellular biology and prognosis of DCIS. The current study did not find any significant impact of P53 on survival because of the low rates of recurrence.

In conclusion, P53 overexpression reflected the aggressiveness and correlated with the invasiveness in DCIS. These findings suggest that P53 may play an important role in the invasion of DCIS in the breast.

\section{Conclusion}

The rate of P53 overexpression was significantly higher in IDC (T1a) than in DCIS, as revealed by the results of univariate analysis, and was significantly associated with positive surgical margin status. Patients with P53 overexpression had significantly lower ER/PgRpositive rates, higher nuclear grade, higher HER2 status, and higher $\mathrm{Ki}-67$ labeling indices in DCIS.

A limitation of this retrospective study is researcher bias that may occur when selecting the patients and treatment method for analysis. In order to deal with this potential problem, multivariable analysis was utilized to control for any confounding variables.

\section{References}

1. Page DL, Dupont WD, Rogers LW, Landenberger M (1982) Intraductal carcinoma of the breast: follow-up after biopsy only. Cancer 49: 751-758.

2. Page DL, Dupont WD, Rogers LW, Jensen RA, Schuyler PA (1995) Continued local recurrence of carcinoma 15-25 years after a diagnosis of low grade ductal carcinoma in situ of the breast treated only by biopsy. Cancer 76: 1197-1200.

3. Cavaliere A, Scheibel M, Bellezza G, Colella R, Vitali R, et al. (2006) Ductal carcinoma in situ with microinvasion: clinicopathologic study and biopathologic profile. Pathol Res Pract 202: 131-135.

4. Nofech-Mozes S, Spayne J, Rakovitch E, Kahn HJ, Seth A, et al. (2008) Biological Markers Predictive of Invasive Recurrence in DCIS. Clin Med Oncol 2: 7-18.

5. Okumura Y, Yamamoto Y, Zhang Z, Toyama T, Kawasoe T, et al. (2008) Identification of biomarkers in ductal carcinoma in situ of the breast with microinvasion. BMC Cancer 8: 287.

6. Han K, Nofech-Mozes S, Narod S, Hanna W, Vesprini D, et al. (2012) Expression of HER2neu in ductal carcinoma in situ is associated with local recurrence. Clin Oncol (R Coll Radiol) 24: 183-189.

7. Provenzano E, Hopper JL, Giles GG, Marr G, Venter DJ, et al. (2004) Histological markers that predict clinical recurrence in ductal carcinoma in situ of the breast: an Australian population-based study. Pathology 36: 221-229.

8. Kerlikowske K, Molinaro A, Cha I, Ljung BM, Ernster VL, et al. (2003) Characteristics associated with recurrence among women with ductal carcinoma in situ treated by lumpectomy. J Natl Cancer Inst 95: 1692-1702.

9. de Roos MA, de Bock GH, de Vries J, van der Vegt B, Wesseling J (2007) p53 overexpression is a predictor of local recurrence after treatment for both in situ and invasive ductal carcinoma of the breast. J Surg Res 140: 109-114.

10. Perin T, Canzonieri V, Massarut S, Bidoli E, Rossi C, et al. (1996) Immunohistochemical evaluation of multiple biological markers in ductal carcinoma in situ of the breast. Eur J Cancer 32A: 1148-1155. 
Citation: Kikuchi S, Osako T, Nishiyama Y, Nakano M, Tashima R, et al. (2014) P53 Overexpression in Ductal Carcinoma in situ of the Breast. J

Page 6 of 6

11. Ringberg A, Anagnostaki L, Anderson H, Idvall I, Fernö M, et al. (2001) Cell biological factors in ductal carcinoma in situ (DCIS) of the breastrelationship to ipsilateral local recurrence and histopathological characteristics. Eur J Cancer 37: 1514-1522.

12. Rajan PB, Scott DJ, Perry RH, Griffith CD (1997) p53 protein expression in ductal carcinoma in situ (DCIS) of the breast. Breast Cancer Res Treat 42: 283-290.

13. Kai K, Nishimura R, Arima N, Miyayama H, Iwase H (2006) p53 expression status is a significant molecular marker in predicting the time to endocrine therapy failure in recurrent breast cancer: a cohort study. Int J Clin Oncol 11: 426-433.

14. Kikuchi S, Nishimura R, Osako T, Okumura Y, Nishiyama Y, et al. (2013) Definition of p53 overexpression and its association with the clinicopathological features in luminal/HER2-negative breast cancer. Anticancer Res 33: 3891-3897.

15. Yamashita H, Toyama T, Nishio M, Ando Y, Hamaguchi M, et al. (2006) p53 protein accumulation predicts resistance to endocrine therapy and decreased post-relapse survival in metastatic breast cancer. Breast Cancer Res 8: R48.

16. Berns EM, Foekens JA, Vossen R, Look MP, Devilee P, et al. (2000) Complete sequencing of TP53 predicts poor response to systemic therapy of advanced breast cancer. Cancer Res 60: 2155-2162.

17. Muller PA, Vousden KH, Norman JC (2011) p53 and its mutants in tumor cell migration and invasion. J Cell Biol 192: 209-218.

18. Cornfield DB, Palazzo JP, Schwartz GF, Goonewardene SA, Kovatich AJ, et al. (2004) The prognostic significance of multiple morphologic features and biologic markers in ductal carcinoma in situ of the breast: a study of a large cohort of patients treated with surgery alone. Cancer 100: 2317-2327.

19. Rodrigues NR, Rowan A, Smith ME, Kerr IB, Bodmer WF, et al. (1990) p53 mutations in colorectal cancer. Proc Natl Acad Sci U S A 87: 7555-7559.
20. Fonseca R, Hartmann LC, Petersen IA, Donohue JH, Crotty TB, et al. (1997) Ductal carcinoma in situ of the breast. Ann Intern Med 127: 1013-1022.

21. Bradley SJ, Weaver DW, Bouwman DL (1990) Alternatives in the surgical management of in situ breast cancer. A meta-analysis of outcome. Am Surg 56: 428-432.

22. Berger CE, Qian Y, Liu G, Chen H, Chen X (2012) p53, a target of estrogen receptor (ER) $\hat{\mathrm{I}} \pm$, modulates DNA damage-induced growth suppression in ER-positive breast cancer cells. J Biol Chem 287: 30117-30127.

23. Olivier M, Langerød A, Carrieri P, Bergh J, Klaar S, et al. (2006) The clinical value of somatic TP53 gene mutations in 1,794 patients with breast cancer. Clin Cancer Res 12: 1157-1167.

24. Fernandez-Cuesta L, Anaganti S, Hainaut P, Olivier M (2011) p53 status influences response to tamoxifen but not to fulvestrant in breast cancer cell lines. Int J Cancer 128: 1813-1821.

25. Dunphy KA, Blackburn AC, Yan H, O'Connell LR, Jerry DJ (2008) Estrogen and progesterone induce persistent increases in p53-dependent apoptosis and suppress mammary tumors in BALB/c-Trp53+/- mice. Breast Cancer Res 10: R43.

26. Ciccone MM, Scicchitano P, Gesualdo M, Fornarelli F, Pinto V, et al. Systemic vascular hemodynamic changes due to $17-\beta$-estradiol intranasal administration. J Cardiovasc Pharmacol Ther 18: 354-358.

27. Ciccone MM, Scicchitano P, Cortese F, Gesualdo M, Zito A, et al. (2013) Modulation of vascular tone control under isometric muscular stress: role of estrogen receptors. Vascul Pharmacol 58: 127-133.

28. Ciccone MM, Cicinelli E, Giovanni A, Scicchitano P, Gesualdo M, et al (2012) Ophthalmic artery vasodilation after intranasal estradiol use in postmenopausal women. J Atheroscler Thromb 19: 1061-1065. 